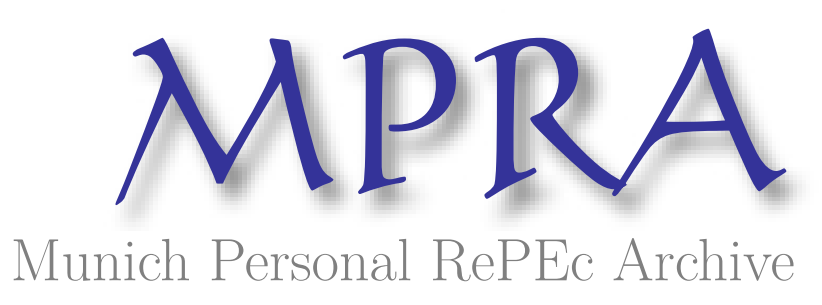

\title{
Is there a Displacement Deadweight Loss from Tax Evasion? Estimates Using Firm Surveys from the Czech Republic
}

Hanousek, Jan and Palda, Filip

École nationale d'administration publique

June 2007

Online at https://mpra.ub.uni-muenchen.de/3911/

MPRA Paper No. 3911, posted 09 Jul 2007 UTC 


\title{
Is there a Displacement Deadweight Loss from Tax Evasion? Estimates Using Firm Surveys from the Czech Republic $^{1}$
}

\author{
Jan Hanousek and Filip Palda
}

June, 2007

In the presence of the underground economy taxes give rise to a deadweight loss from displacement of efficient producers by inefficient producers. We consider an economy in which a producer faces two types of costs: the cost of production, and taxes. If the ability to evade taxes is inversely proportional to the ability to keep production costs down, high tax rates may cause inefficient producers to crowd out efficient producers. We estimate this deadweight loss from surveys of 426 Czech firms taken in 2004 and 2005. We find that the deadweight loss due to this crowding out can be several times as large as the triangle deadweight losses from discouraged consumption. Our paper provides the first estimates ever of the displacement loss from tax evasion.

Keywords: $\quad$ Underground economy; social cost of public funds; taxation.

JEL Classification: H26, H43, K42, O17

Shell Brasil, the Brazilian subsidiary of the Anglo-Dutch oil group, is to sell 285 service stations and six fuel deposits to Agip do Brasil, the local subsidiary of Eni, the Italian group. Shell said the move was part of efforts to concentrate on the most profitable parts of its business in Brazil, but it is understood to have sold the stations, in remote central and western regions of the country, after failing to compete with smaller distributors undercutting bigger companies by evading taxes.

Financial Times of London, February 25, 2000, page 18

\footnotetext{
${ }^{1}$ Jan Hanousek is professor at economics and statistics CERGE-EI, a joint workplace of Charles University and the Academy of Sciences of the Czech Republic. Filip Palda is professor of economics at the École nationale d'administration publique, Montreal, Canada and visiting professor at CERGE-EI . Address for correspondence: CERGE-EI, P.O.Box 882, Politickych veznu 7, 111 21, Prague, Czech Republic. Emails: Jan.Hanousek@ cergeei.cz and Filip_Palda@enap.ca. We gratefully acknowledge funding from the Global Development Network and from the Czech Grant Agency. We thank Randal Filer, Stepan Jurajda, and participants in presentations at various conferences including EEA, CES, GDN, and seminars at Brussels, The Center for the Study of Public Choice at George Mason University, Michigan, Milan, Paris Dauphine, Pensylvania, and Prague for helpful comments on an earlier version of the paper. All simulations in MAPLEV, as well as datasets on firms are available from the authors upon email request and readers are encouraged to modify and further the results presented here.
} 


\section{Introduction}

The present paper seeks to estimate the deadweight loss from the displacement of efficient producers by efficient tax evaders by using surveys of 426 Czech firms taken in 2004 and 2005. Uneven enforcement of taxes creates an uneven playing field on which inefficient producers with a willingness and ability to evade taxes can oust honest, efficient producers from the market. The difference between the costs of the surviving evaders, and what costs would have been without evasion, is the displacement deadweight loss from tax evasion.

Displacement deadweight loss arises from, but should not be confused with the displacement of resources that arises when a government intervention eliminates an economic actor and replaces him with a similar actor. Most research into what is commonly understood as displacement, of which Dahlberg and Forslund (2005) is a representative example, has focused on the question of whether wage subsidies create employment or whether they simply replace non-subsidized labour by subsidized labour. Research has also focused on how subsidies to firms allow one firm to displace the other, but with the exception of perhaps Usher $(1975,1983)$, research has focused on how to measure the amount of displacement rather than on measuring the social cost of this displacement. In the field of taxes almost no research exists on how tax evasion leads to displacement, nor of the cost of such displacement. Vito Tanzi (1982, p.88) is one of the few economists to have noticed that "untaxed underground activities will compete with taxed, legal ones and will succeed in attracting resources even though these activities may be less productive...There will of course be significant welfare losses associated with this transfer." Jonathan Kesselman (1997, p.300) made a related point: "If pure tax evasion is concentrated in particular industries or sectors it will raise net returns from activities in those sectors, and this will in turn tend to expand those sectors and their products as against the efficient pattern arising with uniform compliance."

The lack of interest economists have show in the displacement deadweight loss from taxes may be due in part to the large number of competing ideas about the deadweight losses that arise from tax evasion. Each one of these ideas has important policy implications and has attracted the interests of a growing number of researchers. The most prominent concern about tax evasion is the extent to 
which it narrows the tax base. A small tax base forces a few people to carry a large burden of financing public goods. Browning (1976) called the weight of this burden the social cost of public funds and emphasized that progressively smaller tax bases produce exponentially rising social costs of public funds and government underinvestment in public goods. With these ideas in mind Loayaza (1996) modeled the underground economy and found that it could reduce economic growth if this economy reduced the availability of public services to all. Alm (1985) saw the main cost of the tax evasion as being the fact that the absence of tax in the underground economy drives a wedge between the marginal product of labour in the underground economy and the marginal product of the same labour in the taxed economy. This wedge means that society's overall product would be higher if labour moved back to the taxed economy. Alm estimated losses as high as nine percent of the US economy. Usher (1986) has pointed out that another social cost of tax evasion is the value of the effort people put into concealing their incomes. Cremer and Gahvari (2000) have warned that a state may secretly compete for the tax base of its neighbour by going soft on tax evaders. These authors worry that the "mobility of tax bases between lower level jurisdictions, creates a potential for an efficiency loss due to non-cooperative tax setting" and argue for coordinated tax auditing policies between states and within federal states. More recently Bayer (2006) has examined how enforcement costs vary with tax rates by modeling tax evasion as a "concealment-detection contest" between the taxpayers and the authorities. He showed through simulations that "higher tax rates cause more evasion and increase the resources wasted in the contest." Spiro (2005) provides a recent survey of the literature on the efficiency costs of tax evasion. The bibliographies of these researches contain references to studies with similar objectives, but only Spiro (2005) contains a reference to displacement deadweight loss.

Whether the idea of displacement deadweight loss can find its place among the ideas mentioned above may depend on the answers to three empirical questions which we make the subject of the present paper:

1) The opinion firms hold of competitors who evade tax. Anecdotes abound about how large, wellestablished firms who pay their taxes lobby governments to make smaller firms pay their due. Tax officials explained to one of the authors that in the Canadian province of Quebec during the 1990's hotel chains demanded that government force bed and breakfasts, hostels, and "villages d'accœuil" 
(rural villages that welcome tour groups into their homes) to stop evading taxes because such evasion was eroding hotel chain business. The present paper goes beyond anecdotes and asks a representative sample of firms questions structured to discover whether displacement loss is a phenomenon about which policy makers should worry. We find, in support of the importance of importance of displacement deadweight loss, that a majority of firms believes that tax evaders pose a threat to the existence of honest firms and that evaders tend to be less efficient than honest firms.

2) The correlation between a firm's tax-honesty and its productivity. Palda (1998, 2001a, 2001b) examined the theoretical circumstances under which a displacement loss from uneven enforcement of taxes arises. The amount of loss depends on how closely tied are a firm's productive efficiency and tax-honesty. If efficient producers are honest taxpayers and inefficient producers are dishonest, then a rise in taxes creates a climate that favors the survival of tax evaders above the survival of firms with low production costs. Using a simple model of profit maximizing firms he showed how displacement losses from the tax tend to rise as the correlation between honesty and efficiency rises. Significant displacement deadweight can exist even when there is no correlation between honesty and efficiency. Only in the case where there is a perfect negative correlation between the efficiency of a firm and its tax-honesty did Palda find an absence of displacement deadweight loss. Guided by Palda's model, we use our firm surveys to calculate correlation of between 0.1368 and 0.1673 , which suggest that significant displacement deadweight loss may plague certain sectors of the Czech economy.

3) Is displacement deadweight a phenomenon of comparable importance to, say, Alm's (1985) deadweight loss from evasion? Alm found deadweight losses of $9 \%$ for the US. We estimate, under highly stylized assumptions about production functions and tax schedules, that displacement deadweight losses can be in the neighborhood of $2.7 \%$ to $13.1 \%$ of industry costs.

We emphasize that even though this paper analyses data, it does not test a hypothesis. We follow the research agenda started by Harberger (1964) of building a model of deadweight loss, and of using data about the economy to calculate the parameters that belong in the model. We load these parameters into a model to produce estimates of deadweight loss. These estimates will only be as good as the model and the quality of the data used to flesh out the model. In this paper we take 
pains to examine both the quality of our model and of our data in judging whether displacement deadweight loss is a phenomenon worthy of further study.

The plan of the paper is as follows. Section two explains the notion of displacement deadweight loss. Section three describes our firm survey and explains how the results of the survey support the notion that displacement loss exists and might be large enough to merit further study. Section four uses our firm survey to produce calculate the correlation between productive efficiency and tax honesty. Section five suggests how to measure displacement deadweight loss and provides estimates based on our survey. Section six points out where the present research needs to be deepened.

\section{What is displacement deadweight loss?}

Displacement deadweight loss arises because by virtue of their ability or willingness to evade taxes some firms with high production costs oust from the market firms with low production costs. The difference between actual industry production costs and what those costs would have been if only the most efficient producers had survived is displacement deadweight loss (which we will call DDL). In earlier work cited above, Palda gave precision to the above notion by modeling firm competition in the presence of two characteristics that "code" for survival. The two characteristics he considered are efficiency in production and tax-honesty. Two parameter survival models in economics are common, but Palda's was the first two parameter survival model where one parameter is socially productive while the other may be destructive. From the opposite social usefulness of each factor arises the potential for a DDL.

DDL would not be a topic of interest to researchers if the most efficient producers were also the most active tax evaders. In such a case an inefficient producer would not have the tax evading advantage that would allow him to oust a more efficient producer. Put differently, when productive efficiency and tax honesty are perfectly negatively correlated, DDL is zero. DDL arises when productive efficiency and tax honesty are not perfectly negatively correlated. Consider the story a flower merchant from the Czech Republic told us. This merchant would import flowers from 
Holland in refrigerated truck and pay full duty at the Czech border. Some of his competitors would bring flowers back from Holland undeclared and concealed in the unrefrigerated trunks of their car. His competitors were willing to let half their flowers wilt to evade taxes because such a maneuver gave them a cost advantage over him. While his production costs were lower (lower wastage of flowers) his overall tax and production costs were higher and he was being edged out of the market. The difference between the production costs of the tax evaders and what costs would have been had the honest merchant been the sole supplier is the DDL.

Palda found through simulations that, over a broad range of correlations, DDL falls as the correlation between tax honesty and productive efficiency rises. Put differently, if many efficient producers also pay much of their tax they will be prey to inefficient producers who pay little of their tax. Palda was surprised to make prominent measure of DDL even when productive efficiency and tax honesty were uncorrelated. He explained this by pointing out that in the uncorrelated case a producer is as likely to be efficient and honest as inefficient and dishonest and that some cases will arise where a producer's lack of honesty allows him to overcome his lack of efficiency and oust a more efficient but more honest rival. Palda could not generalize his results, as

they arose from simulations based on the assumption that efficiency and honesty are either uniformly distributed or joint-normally distributed, and on assumptions of a Cobb-Douglass production function. For the present research Palda's results suggests we should be on the lookout for a correlation between efficiency and honesty that is greater than -1. A correlation in the neighborhood of zero or greater may suggest, but by itself not prove, the existence of a large DDL.

\section{The Firm Survey}

The previous section suggests that the correlation between productive efficiency and honesty is the key variable of interest to those interested in the potential existence of DDL. Measuring such a correlation is not at first an obvious exercise and in this section we work towards such a measure by first getting some idea of the spread of efficiency and honesty and of whether firms believe displacement to be a competitive threat. 
Table 1: Those Who Answered our Survey

\begin{tabular}{l|l|l|l}
\hline \hline Working position & Frequency & Percent & Cumulative \\
\hline \hline Company owner & 305 & $71.6 \%$ & $71.6 \%$ \\
\hline \hline Director of the company/division & 17 & $4.0 \%$ & $75.6 \%$ \\
\hline \hline Manager with subordinate departments & 104 & $24.4 \%$ & $100.0 \%$ \\
\hline \hline TOTAL & 426 & $100.0 \%$ & \\
\hline \hline
\end{tabular}

We begin with some simple questions we posed to firms about their beliefs concerning evasion and efficiency in their industry. Our data on firms come from combined 2004 and 2005 surveys of 107 and 319 Czech firms, respectively. These firms were drawn from retail (220 firms) and construction (206 firms). Respondents were of three kinds as summarized in Table 1. The large percentage of respondents who were company owners gives us confidence that our survey will pick up the best available knowledge about the underground economy facing the firms interviewed.

Table 2: Spread of Productive Efficiency of Firms

Question: "How big are the differences in productivity of companies in your line of business?"

\begin{tabular}{l|c|c|c}
\hline \multicolumn{1}{c|}{ Differences in productivity } & Frequency & Percent & Cumulative \\
\hline Very big & 46 & 10.8 & $10.8 \%$ \\
Rather big & 123 & 28.9 & $39.7 \%$ \\
Big & 81 & 19.0 & $58.7 \%$ \\
Rather small & 126 & 29.6 & $88.3 \%$ \\
Small & 50 & 11.7 & $100.0 \%$ \\
\hline \hline TOTAL & 426 & 100.0 & \\
\hline \hline
\end{tabular}

Table 2 indicates that $58.7 \%$ of respondents believed there was a large spread in productivity. Displacement deadweight loss cannot arise without a spread in productive talents and the larger the spread, there greater is the potential for DDL. 
Table 3: Efficiency in Production vs. Firm Size

Question: "Which companies tend to evade paying taxes?"

\begin{tabular}{l|c|c|c}
\hline \hline $\begin{array}{c}\text { Which companies evade taxes, by } \\
\text { number of employees (2005) }\end{array}$ & $\begin{array}{c}\text { Agree } \\
\text { (percent) }\end{array}$ & $\begin{array}{c}\text { Disagree } \\
\text { (percent) }\end{array}$ & $\begin{array}{c}\text { Confident interval for } \\
\text { Percent of evading }\end{array}$ \\
\hline More than 100 employees & 57.7 & 42.3 & $(26.833 .9)$ \\
50-99 employees & 57.4 & 42.6 & $(23.429 .4)$ \\
6-49 employees & 52.3 & 47.7 & $(22.328 .0)$ \\
Less than 5 employees & 48 & 52 & $(24.931 .6)$ \\
Only 1 employee & 51.4 & 48.6 & $(28.135 .2)$ \\
\hline \hline TOTAL number of firms & 319 & 100 & \\
\hline \hline
\end{tabular}

A common belief among those who believe in displacement deadweight loss is that small firms are inefficient and resort to tax evasion to out-compete large firms. Table 3 gives mixed support to this notion. Small firms do not seem more likely to evade than large firms. In fact, there is a bias in Table 3 towards the argument that large firms are the biggest evaders. The questions we posed were not subtle enough to discern what percentage of its revenues a firm evaded, so we must regard cautiously the figures in Table 3. Note that the total number of firms in Table 3 is 319 because Table 3 is based only on the 2005 survey. We did not include the 2004 survey in Table 3 because then we asked a similar, but poorly worded question.

Table 4: Are Evading Firms a Threat to Honest Firms?

Question: "Do you agree with the opinion that companies that evade paying taxes threat your business?"

\begin{tabular}{l|c|c|c}
\hline \hline \multicolumn{1}{c|}{ Are evading firms a threat to honest firms? } & Frequency & Percent & Cumulative \\
\hline Definitely agree & 183 & 43.0 & 43.0 \\
Rather agree & 118 & 27.7 & 70.7 \\
Neither agree nor disagree & 31 & 7.3 & 77.9 \\
Rather disagree & 69 & 16.2 & 94.1 \\
Definitely disagree & 25 & 5.9 & 100.0 \\
\hline \hline TOTAL & 426 & 100 & \\
\hline \hline
\end{tabular}


Table 4 presents evidence on why firms fear tax evasion by their rivals. Fully 70.7 of firms believed that firms that evade taxes are a threat to their existence. Table 4 gives support to the notion that tax evasion is a threat to the survival of most firms.

Table 5: Do Companies Evade Taxes to Survive?

Question: "Do you think that companies try to evade paying taxes because in case they pay taxes in full firms will not survive?"

\begin{tabular}{l|c|c|c}
\hline \multicolumn{1}{c|}{ Do companies evade saxes to survive? } & Frequency & Percent & Cumulative \\
\hline Definitely yes & 143 & 33.6 & 33.6 \\
Rather yes & 161 & 37.8 & 71.4 \\
Rather no & 87 & 20.4 & 91.8 \\
Definitely no & 35 & 8.2 & 100.0 \\
\hline \hline TOTAL & 426 & 100.0 & \\
\hline \hline
\end{tabular}

Table 5 may hint that inefficient firms are the most frequent tax evaders as $71,4 \%$ of respondents believed evasion is a method of survival in the market.

Table 6a: Is There a Relation Between Productive Efficiency and Evasive Ability? Question: "Is there any relation between tax evasion and efficiency of the company?"

\begin{tabular}{l|c|c|c}
\hline \hline Relationship between evasion and efficiency & Frequency & Percent & Cumulative \\
\hline Definitely yes & 102 & 23.9 & $23.9 \%$ \\
Rather yes & 174 & 40.8 & $64.8 \%$ \\
Rather no & 117 & 27.5 & $92.3 \%$ \\
Definitely no & 33 & 7.7 & $100.0 \%$ \\
\hline \hline TOTAL & 426 & 100 & \\
\hline \hline
\end{tabular}


Table 6b: What is the Extent of the Relation between Productive Efficiency and Evasive Ability? Question: "What is the relation between evasion of paying taxes and efficiency of the company?"

\begin{tabular}{l|c|c|c}
\hline \hline Relation between tax evasion and efficiency & Frequency & Percent & Cumulative \\
\hline Definitely positive & 44 & 10.3 & $10.3 \%$ \\
Rather positive & 96 & 22.5 & $32.9 \%$ \\
Rather negative & 101 & 23.7 & $56.6 \%$ \\
Definitely negative & 35 & 8.2 & $64.8 \%$ \\
I do not know & 150 & 35.2 & $100.0 \%$ \\
\hline \hline TOTAL & 426 & 64.8 & \\
\hline \hline
\end{tabular}

Tables $6 \mathrm{a}$ and $6 \mathrm{~b}$ give a more precise sense of the possible correlation between tax-honesty and efficiency than do the tables that precede them. Table 6a suggests that $64.8 \%$ of firms believe that tax evasion and productive efficiency are related. Just what this relation might be though seems hard to infer from Table $6 \mathrm{~b}$ which suggest that as many believe the relation between efficiency and tax-honesty to be positive and those who believe the relation to be negative.

Tables 1-5 tend to give support to the notion that displacement deadweight loss is a phenomenon of concern to firms in the Czech Republic. Tables 6(a) and 6(b) frustrate our attempts to get a clear idea of what is the correlation between tax honesty and efficiency. DDL falls as this correlation falls (though DDL does not disappear completely, according to theoretical results, until the correlation is -1), so a precise idea of the correlation would help us decide whether policy makers should worry about DDL.

\section{Calculating the correlation between efficiency and honesty}

Up to this point we have loosely spoken of a firm's productive efficiency and tax honesty. To calculate the correlation between productive efficiency and tax honesty we need to sharpen our definition of these two quantities and explain how each firm becomes endowed with them.

Think of producers as being infinite in number and indexed by $A$. $A$ is a productivity parameter that differs from firm to firm. Each firm is also given a different index $i$ which is an honesty parameter. A high $i$ signifies the firm pays most of its taxes. Nature grants each firm its $A$ and $i$ by 
drawing from a distribution $f(A, i)$ in a Cartesian coordinate system where both $A$ and $i$ span $[0,1]$. Later we explain how this formulation of a firm's efficiency and honesty can be used to calculate DDL. For the moment we wish to focus on calculating the correlation between honesty and efficiency. For the moment we also put away explaining where the honesty parameter comes from.

To calculate this correlation we need to know the joint distribution of $A$ and $i$. To get an idea of the joint distribution of evasive and productive abilities we asked firms their opinions. We presented each firm with a five-by-five matrix with evasive ability on one axis and productive ability on the other axis. We asked each firm to state what percentage of firms in their industry they believed fell into each of the twenty-five cells of the evasion-productivity matrix. As mentioned earlier, our data on firms come from a combined 2004 and 2005 surveys of 107 and 319 Czech firms, respectively. These firms were drawn from retail (220 firms) and construction (202 firms).

Figure 1 shows the distribution of firm answers weighted to achieve representativeness. The answers of each firm were forced to sum to $100 \%$ by a $\mathrm{Java}^{\mathrm{TM}}$ algorithm. Firms answered the question on the joint distribution of evasive and productive abilities by entering an internet site that forced their answers to sum to one by not allowing respondents to finish until their answers summed to one. The algorithm designed to achieve such consistency was devised specifically for the purposes of this study by the Czech survey firm Median.

A quick glance at Figures 1(b) and 1(c) suggests that firm opinions about the underground economy are similar in the construction and the retail sectors. We carried out a chi-square test of homogeneity of distributions and did not reject ( $\mathrm{p}$-value=0.66) at convention levels the hypothesis that the two distributions are the same. The results of the chi-square test led us to pool firm answers from both construction and retail sectors. The pooled data can be seen in Figure 7(a) and it is these data we use in calculating the correlation between efficiency and honesty, as well as in our later calculations of DDL.

We tested whether the distributions were uniform and whether efficiency and honesty were statistically independent. A positive answer to either or both of these questions could indicate that 
respondents filled out their matrices randomly, due perhaps to "answer fatigue." Using a Pearson Chi-square test we rejected with $P$ values below 0.0001 the hypothesis that $A$ and $i$ are statistically independent. We also rejected with similar confidence the hypothesis that the joint distribution of $A$ and $i$ is uniform and symmetric. We conclude that our respondents did not fill out the $A-i$ matrix randomly.

Figure 1: Joint Distribution of Firm Evasive and Productive Abilities (all firms)

A) All firms

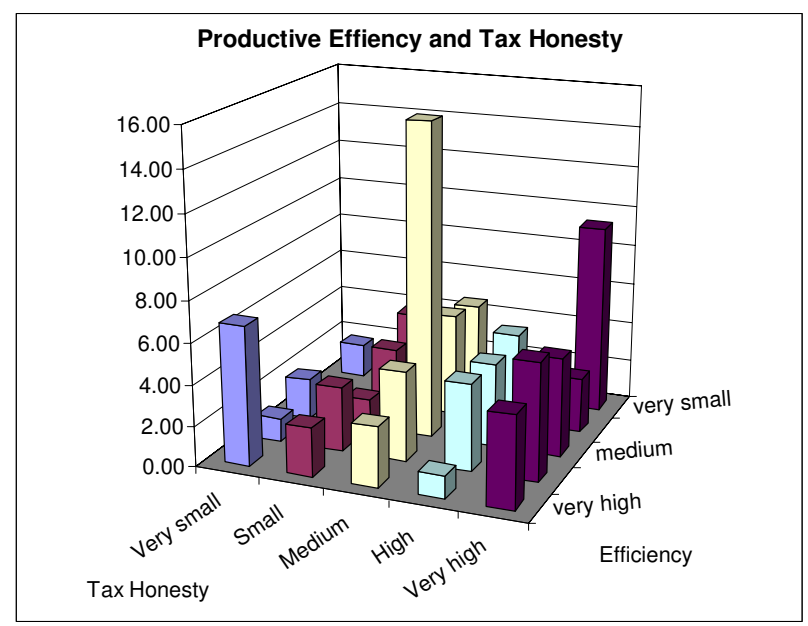

B) Retail

C) Construction
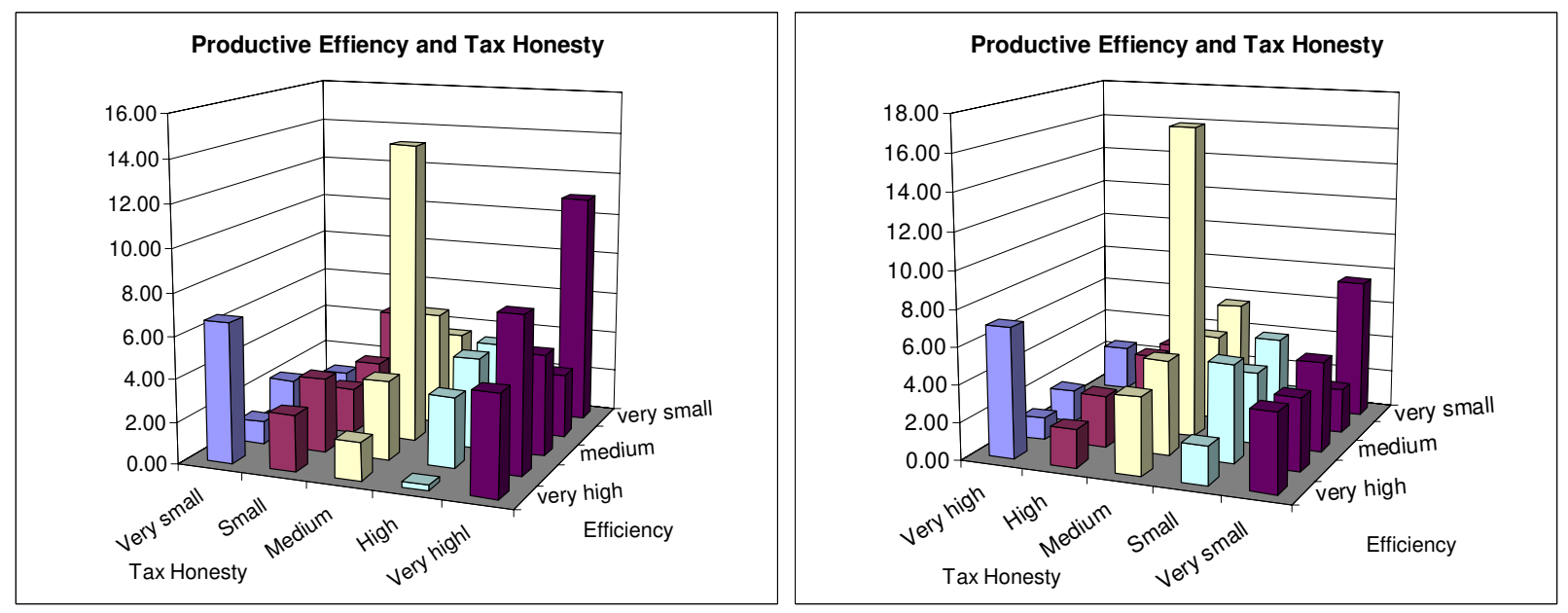

Of the available measures of correlation in ordinal data we chose the most common: Spearman's rank correlation coefficient and Kendall's tau rank correlation coefficient. Spearman's coefficient was 0.1673 and was significantly different from zero. Kendall's tau-a coefficient (which makes no 
adjustment for ties in the cross-tabulation) was 0.1067 and the tau-b coefficient (which makes adjustments for ties and is best suited to square cross-tabulations) was 0.1368 with both being significantly different from zero.

In Palda's simulations, even a zero correlation between honesty and efficiency produced significant DDL. A positive correlation between efficiency and honesty produced even more DDL. Our calculated correlations suggest that DDL may be a significant problem in the certain sectors of the Czech economy.

\section{An estimate of displacement deadweight loss}

To measure displacement deadweight loss we need to know what are the costs of firm production under tax evasion and then to compare this cost to what costs would be if firms did not evade taxes $^{2}$. In a market where firms either survive or perish, the exercise of measuring DDL is to first identify the firms who produce under evasion, the amount they produce, and measure their production costs. The second step is to identify who would be the most efficient firms to produce the quantity produced under evasion, and to measure their production costs. DDL is the difference in the costs of production of the two groups of firms. If both groups of firms are identical to each other then no DDL arises. The less overlap there is between the two groups of firms, the greater is DDL. The whole trick to measuring DDL is to identify the two groups of firms and then compare their costs.

To identify firms who survive from the set of all possible firms we specify a criterion for survival. We assume a firm survives if its costs are inferior to price. Assume all firms have the same perceived cost function $C(A, i T)$ where $i T$ are taxes paid (the firm pays a percentage $i$ of its taxes $T$ ). We say perceived costs because the firm counts not only production costs, but taxes as a part of costs. Palda used the following cost function (which arises from a Cobb-Douglass production function with constant returns to scale, a factor tax $\mathrm{T}$, and wages and rents equal to 0.5 ) in his firm survival criterion:

\footnotetext{
${ }^{2}$ For a more technical exposition of theory behind the measurement of DDL please see Palda (2001b) at http://ideas.repec.org/p/wpa/wuwppe/0111006.html
} 


$$
C=\frac{1+i T}{A}
$$

Equation (1) shows the costs a firm perceives. Its true production costs, which are the key to calculating DDL, are $1 / A$.

A firm survives if its perceived cost $C$ is below price $P$. Cost less than price means that (using equation 1), a firm survives if its efficiency parameter $A$ satisfies the following condition:

$$
A \geq \frac{1+i T}{P}
$$

Equation (2) is a line which divides those firms who survive from those that do not survive. We show equation (2) in two perspectives. The first perspective is in Figure (2)

\section{Figure 2: A Bird's-eye view of firm survival}

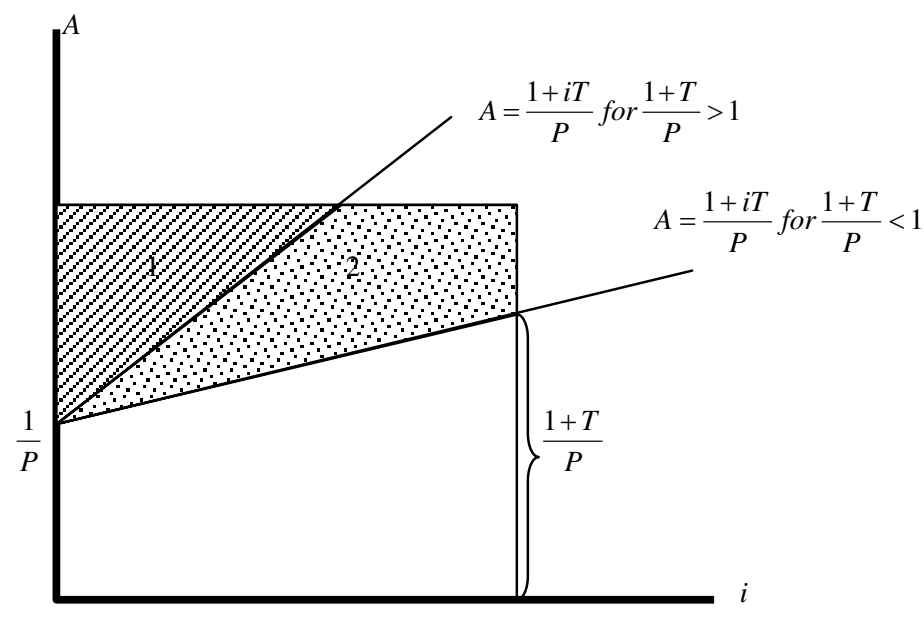

If $(1+T) / P>1$ then firms with the combinations of productivity parameter $A$ and evasion parameter $i$ in the shaded area 1 , are those firms who produce. If $(1+T) / P<1$ firms in the area 1 and 2 produce. Figure (2) is a bird's-eye view of the efficiency-honesty matrix that firm's in our survey filled-out and which we saw in three dimensions in Figures 1(a)-(c). 


\section{Figure 3: A three-dimensional view of firm survival}

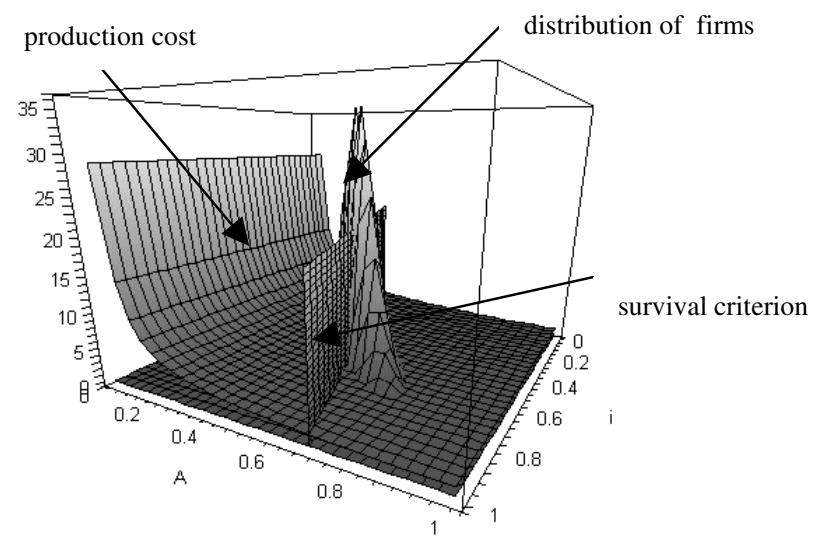

Figure (3) adds to Figure (2) a distribution function of firms and a cost of production function $1 / A$ that falls out of the Cobb-Douglas production function under assumptions stated earlier. This cost of production is the curved plane that slopes down as $A$ rises. The distribution function is the hump in the middle of the graph. We chose a normal distribution function for reasons of exposition. The straight plane that cuts through the distribution is the survival condition represented in equation (2). Firms to the right of the straight plane are those with the combinations of $A$ and $i$ necessary to survive given taxes and prices. Total industry production cost is the height of the sum of costs weighted by frequency to the right of the straight plane. Displacement losses are these costs less the least possible costs of producing industry output.

The above paragraph gives us the three ingredients we need to calculate DDL:

1) A distribution function of firms in efficiency-honesty $(A, i)$ space.

2) A survival criterion; the line $A=(1+i T) / P$.

3) A cost function, which in our case we chose as $1 / A$.

With these ingredients we follow three steps

1) Calculate market equilibrium output given some fixed tax level $T$ and fixed market price $P$. 
2) Calculate the cost of producing market equilibrium output.

3) Calculate the cost of producing equilibrium output by the most efficient producers.

Displacement deadweight loss is the difference between (2) and (3).

The distribution function is our three-dimensional Figure 1(a), which can be represented in twodimensional form in Table (7) below. The numbers in the cells are the averages of firm answers to the question of the relative frequency of the joint distribution of productive efficiency and tax honesty. For example, the figure of 6.80 in the top-left cell indicates that on average respondents believed that $6.8 \%$ of firms in their industry placed in the category of having very low tax-honesty but very high productive efficiency.

Table 7: Relationship Between Tax evasion and Production Efficiency

\begin{tabular}{|c|c|c|c|c|c|c|c|}
\hline \multicolumn{2}{|c|}{$\begin{array}{l}\text { PRODUCTION } \\
\text { EFFICIENCY }(A)\end{array}$} & $\begin{array}{ll}\text { very } & \text { low } \\
(0.2) & \end{array}$ & $\begin{array}{l}\text { low } \\
(0.4)\end{array}$ & $\begin{array}{l}\text { medium } \\
(0.6)\end{array}$ & $\begin{array}{l}\text { high } \\
(0.8)\end{array}$ & $\begin{array}{l}\text { very high } \\
\text { (1.0) }\end{array}$ & TOTAL \\
\hline \multirow{2}{*}{$\begin{array}{c}\text { High } \\
\text { efficiency }\end{array}$} & very high (1) & 6.80 & 2.37 & 2.93 & 1.11 & -4.48 & 17.70 \\
\hline & high $(0.8)$ & 1.14 & 3.16 & -4.38 & 4.27 & 5.73 & 18.68 \\
\hline$\Downarrow$ & medium $(0.6)$ & 1.99 & 1.40 & 15.39 & 4.11 & 4.82 & 27.72 \\
\hline \multirow{2}{*}{$\begin{array}{c}\text { Low } \\
\text { efficiency }\end{array}$} & small (0.4) & 0.05 & 2.88 & 5.04 & 4.50 & 2.72 & 15.20 \\
\hline & very low $(0.2)$ & 1.68 & 3.69 & 4.57 & 1.44 & 9.32 & 20.70 \\
\hline \multicolumn{2}{|c|}{ TOTAL } & 11.66 & 13.51 & 32.32 & 15.43 & 27.09 & 100.00 \\
\hline & & \multicolumn{5}{|c|}{ TAX HONESTY $(i)$} & \\
\hline & & \multicolumn{5}{|c|}{ Low honesty } & \\
\hline
\end{tabular}

We assume perfectly elastic demand so we can fix price $P$ at the arbitrary level of 2 . Taxes are set at 1 so that the survival criterion line becomes $A=(1+i) / 2$, which we represent in the coordinate system of Table 7 as a sloped line bisecting the matrix. Firms above the line are identified by shaded boxes, and these are the firms that survive. Firms below the line do not survive. Drawing 
on the analogy with Figure 3 we can see that the number of firms who produce is the sum of frequencies in the shaded cells. To be explicit, supply under evasion is:

$$
\begin{aligned}
Q_{\text {evasion }}^{s} & =6.80+2.37+2.93+1.11+4.48 \\
& +1.14+3.16+4.38 \\
& +1.99=28.36
\end{aligned}
$$

Costs when firms evade are (1/A) multiplied by the relative frequencies in the colored cells,

$$
\begin{aligned}
C_{\text {evasion }} & =\left(\frac{1}{1}\right) 6.8+\left(\frac{1}{1}\right) 2.37+\left(\frac{1}{1}\right) 2.93+\left(\frac{1}{1}\right) 1.11+\left(\frac{1}{1}\right) 4.48 \\
& +\left(\frac{1}{0.8}\right) 1.14+\left(\frac{1}{0.8}\right) 3.16+\left(\frac{1}{0.8}\right) 4.38 \\
& +\left(\frac{1}{0.6}\right) 1.99=31.86
\end{aligned}
$$

To measure displacement loss we need to compare the above costs to costs in a world which produces the same quantity but is free of tax evasion. To get these costs we simply add the costs of the most efficient firms that could produce 28.36. This cost comes to 31.03 and can be read off Table 7 by simply taking the most efficient $28.36 \%$ of firms and summing their costs. To be sure the method is clear first we sum the frequencies in the top row of Table 3 and multiply by costs. This gives $17.7 *(1 / 1)$ because costs are $1 / A$ and $A$ for this row is 1 . Then we take the difference between 28.36 and 17.7 , which is 10.66 , and multiply this by the costs of the firms in the row which is second from the top in Table 7 . The costs in the row are $1 / A$, or $1 / 0.8=1.25$. The total cost of the most efficient way of producing 28.36 are then

$$
C_{\text {noevasion }}=17.7\left(\frac{1}{1}\right)+(28.36-17.7)\left(\frac{1}{0.8}\right)=31.03
$$

The displacement loss is the percentage difference between costs under evasion and no evasion which comes to $2.7 \%$.

Table 8 measures the displacement loss for a variety of tax levels. Tax levels are, as before, unit taxes on capital and labour. The table also measures tax revenues and displacement loss per unit 
of tax dollar raised for each different tax level. This latter measure is analogous to the social opportunity cost of public funds discussed by Usher (1982).

Table 8: Displacement loss and tax revenues for different levels of taxes

\begin{tabular}{|c|c|c|c|c|}
\hline Tax level & $\begin{array}{l}\text { Absolute } \\
\text { displacement } \\
\text { loss }\end{array}$ & $\begin{array}{l}\text { \% Displacement } \\
\text { loss }\end{array}$ & $\begin{array}{l}\text { Government tax } \\
\text { revenue }\end{array}$ & $\begin{array}{l}\text { Displacement } \\
\text { loss per dollar of } \\
\text { tax revenue }\end{array}$ \\
\hline 0.0 & 0.00 & $0.0 \%$ & 0.00 & 0.00 \\
\hline 0.5 & 0.00 & $0.0 \%$ & 11.83 & 0.00 \\
\hline 1.0 & 0.83 & $2.7 \%$ & 13.95 & 0.06 \\
\hline 1.5 & 1.95 & $9.8 \%$ & 14.21 & 0.14 \\
\hline 2.0 & 0.98 & $5.3 \%$ & 11.91 & 0.08 \\
\hline 2.5 & 1.61 & $13.1 \%$ & 7.34 & 0.22 \\
\hline
\end{tabular}

That government revenues rise and fall is due to the initially inelastic and then elastic contraction of supply in response to tax increases. This Laffer effect is of peripheral interest to the present paper. The rise, fall, and then rise in percentage displacement loss are due to the irregular disposition of firms on the matrix represented in Table 7 and Figure 7. Displacement loss as a percentage of the value of output is comparable to Harberger's triangle calculations for the US. Displacement as a fraction of dollars raised in taxes is comparable to social opportunity cost of government funds presented by Usher (1982).

\section{Challenges to the analysis}

In the present paper we have asked three questions of increasing complexity. Increasing complexity opens our results to increasing chances of false inference. Our first query found that firms in the retail and construction sectors of the Czech Republic find that tax evaders may have an unfair advantage over non-evaders. Opinions were mixed on whether these evaders were of high or low productive efficiency. Our second query pushed the survey into a speculative terrain where firms were asked to fill out a 5 X5 matrix so as to show how productive efficiency and tax honesty were distributed among twenty-five categories. Analysis of the matrix revealed a Spearman rank 
correlation of 0.1673 and a Kendall tau-b of 0.1368 , which suggested the possibility that displacement deadweight loss could be significantly above zero. The third part of the paper presented a formal theory of displacement deadweight loss and suggested that, under highly stylized assumptions about cost functions and taxes, industry displacement loss could be could be of the order of $2.7 \%$ to $13.1 \%$ of costs. In the present section we examine the bias and other challenges that may affect our answers. Some challenges we can counter. Others we have no immediate solutions to.

\subsection{Challenges arising from the survey}

As our first two answers were not based on formal theory, the potential error lies in answers to the survey. Three biases challenges present themselves:

1) What do respondents understand by "tax evasion"? We asked respondents their opinions about tax evasion and accepted their answers without knowing what activities they had in mind when replying. If respondents had tax avoidance in mind when answering questions about tax evasion, survey answers may underestimate the gravity of displacement deadweight loss. A productive firm may hire the best tax consultants and so avoid, through creative accounting, the better part of its taxes. If respondents see this as tax evasion our survey will give the impression that the most productive firms are the most evasive. We might then draw the conclusion that there is less displacement deadweight loss than there is actually. Luckily, unanticipated information volunteered by respondents can address the above problem. Interviewers reported that outside the structure of the survey, most small firms said large firms engaged widely in legal "tax optimization". Tax optimization is a direct translation from the Czech and means tax avoidance. Since smaller firms believed themselves not to have the option of access to expensive tax counseling services they viewed avoidance as evasion. This is evidence that our survey lead to an underestimation of DDL.

2) How knowledgeable are respondents? It is difficult to ascertain how much would firm managers or owners know about other firms in their industry. For example, food retailing 
has three major sectors: supermarkets, chain convenience stores, and corner grocers. How might a manager of a supermarket know about evasion in other sub-sectors of retail, and how might a grocery operator know about evasion by supermarkets? We are not sure that the above problem leads to bias in our answers. It will certainly contribute to noise in the answers. We speculate that firms are likely to know the conditions of their industry better than any other type of respondent. Firms that have survived "long enough" will know who their competitors are and will have an idea of why their competitors are successful. The first part of our survey asked firms whether they believed tax evaders could displace honest firms. The people best placed to answer this question are firms in the industry. Firms who have been around the longest will have the best knowledge of industry conditions. Future surveys might use only the answers of firms who have survived longer than the median number of years of survival in their industry. Future surveys might also try to find objective data on who are the evaders in each industry and use these true answers to test the knowledge of respondents. Respondents with a failing grade would be removed from the sample.

3) How can you map qualitative answers onto a continuous scale? The 5X5 matrix we presented respondents does not ask for them to assign a precise value of A or I to firms but rather to categorize firms into twenty-five slots. How do we know what differing firms mean by high, low, or medium? Starting with Theil (1952) statisticians and economists have been devising methods to covert qualitative data into quantitative data. The literature surveys by Nardo (2003) and D'Elio (2005) underline three methods (probability, regression, latent factor) for transforming qualitative data. None of these methods is at present applicable to our paper because each relies was devised to forecast growth rates of a variable, such as inflation, from people's assessment of whether the variable with rise, fall or stay constant. The methods rely on a time series of answers that draw on revealed quantities from the past to convert current qualitative answers into quantitative answers. There is an outside chance of applying the probability method to our analysis, but such an application would be burdened by questionable assumptions about the indifference range of quantities that respondents identify with a category, and about the distribution of the quantities underlying the qualitative answers. When confronted with ambiguous data, the procedure in simulations is to carry out the simulations by varying assumptions. A glance 
at Table 7 shows that we assumed an answer placing a firm in the upper left cell of the table gave that firm $(A=1, i=0.2)$, in other words, we assumed that respondents had an $A$ of one and an $i$ of 0.2 in mind when thinking of a firm as highly efficient but also very dishonest. We could also have assumed a firm had the mid-point of each cell in mind, so that the upper left cell would correspond to values of $(A=0.9, i=0.1)$, and similarly for all other cells. In simulations shown here we found our measures of DDL did not changed by several percent but remained within the same order of magnitude, which indicates a certain robustness of result.

\subsection{Challenges to the theory}

Our treatment of the theory of displacement loss has been cursory because, in part, much of this theory already has been developed in earlier work by Palda. What one will not find in Palda are the following problems that have to do with the intersection of theory and measurement:

1) Why not model the firm's decision to evade? In the present paper we simply assumed a continuum of firms having what we casually referred to as differing levels of tax honesty. We summarized these evasive abilities in a single random variable $i$ and by so doing ignored all modeling on the decision to evade that has appeared since Allingham and Sandmo's (1972) pioneering work. Instead, we could have endogenized evasion by postulating each firm's evasive decision function. The solved-out decision function of the firm could then be used to identify relevant parameters to estimate from a firm survey and the form in which these estimates must be cast to calculate displacement loss. It might appear that a model of a firm's decision to evade would endogenize the $i$ parameter and lead to a deterministic relation between a firm's productive ability, its aversion to risk, and its innate talents for hiding from the revenue service and by so doing would do away with the need to estimate distributions of evasive and productive abilities. Such a model would no doubt endogenize the evasive decision of each firm but firms would still differ in their aversion to risk, their raw abilities to evade, and their productive abilities. An equilibrium model based on individual firm choices would still leave us with a randomly assigned honesty index $i$, with the only difference from the present discussion being that this random 
variable would itself be the function of other random variables such as firm preference parameters and firm abilities to evade taxes. The value of modeling firm decisions is that it would give testable hypotheses about the joint distribution of $A$ and $i$. As we have emphasized, we are not seeking to test hypotheses. We are searching for a joint distribution between $A$ and $i$, and as we are not setting out to test hypotheses about this joint distribution, but rather to use it in calculations, we have no need to model $i$.

2) Exactly what distribution are firms giving us? The astute reader will notice a quandary in our formulation of the joint distribution function of firms. We asked existing firms to comment on their view of the market as it is. Our theory postulates a distribution over existing and potential firms. Nothing says that the existing distribution is the same as the potential distribution. Our analysis assumes both distributions to be the same. This will be the case if the normalized distribution of $A-i$ of those remaining is identical to the distribution over potential firms. If the normalized distribution is not the same then we can say little of how our results would differ from the true results.

3) Constant production by each firm. Some readers will not like the assumption that all firms produce $d q$. One main channel by which the underground economy might lower efficiency might be by inducing firms to remain suboptimally small in a world of increasing returns to scale so as to avoid coming to the attention of the tax authorities. While it would be possible to model this particular deadweight cost of tax evasion by using a non-linear cost of avoidance that does not rely on the ad hoc assumptions about correlations, such modeling would be addressing not displacement loss, but the loss from staying suboptimally small. While we did not model the above case, Palda (2001b) modeled displacement loss when firms can vary their outputs and evasive and productive talents follow a normal distribution. He found the theoretical estimates of displacement loss to be very similar to the case of fixed firm output.

4) Arbitrariness of taxes and cost function. We used a Cobb-Douglas production function to derive costs under particular assumptions about wages, rents, returns to scale and the tax system (an equal tax on the quantity of labour and capital used). These assumptions produced a straight firm "decision wall." By postulating other cost functions we would have obtained different decision walls (some non-linear) and so different initial equilibrium levels of production and DDL. For reasons of space and exposition we cannot discuss how 
our results vary with different costs and tax functions. Our main objective was to show how such calculations may be done.

\section{Conclusion}

We have asked whether displacement deadweight loss is a topic worthy of study alongside other deadweight losses that arise from tax evasion. To answer this question we first surveyed firms about what they think of tax evaders in their industry. A majority of firms believed evaders stole business from them. Roughly half our respondents thought that evaders were also less efficient than non-evaders. These answers gave some support to our notion that firms with poor productive abilities but a willingness or ability to evade taxes (which we called tax honesty) can oust from the market more efficient, more honest firms. We deepened our analysis by asking firms questions that allowed us to calculate the correlation between efficiency and tax honesty to be above zero. As Palda showed theoretically (1998, 2001a) and by simulation (2001b) a positive correlation produces a significant DDL. Our final step was to apply Palda's model to our data on the joint distribution of efficiency and tax honesty in order to calculate DDL. We found that a DDL comparable to the measures of deadweight loss calculated by Alm (1985).

It is difficult to end an article in public finance without claiming that one's analysis has important policy conclusions. We avoid applying our finding to policy because we have not addressed deadweight loss from taxation in its totality. What matters for policy is the marginal cost of raising an extra dollar of tax income. DDL adds to the total cost, but attacking DDL may change the marginal cost in a surprising way. Palda (2001b) showed that the maximum possible of government revenues might be higher with tax evasion than without it provided there was a strong positive relation between efficiency and honesty. Evasion in such a case allows government to tax discriminate in such a way that firms pay according to their abilities to pay. Reducing tax evasion would then reduce government revenues without necessarily reducing traditional triangle deadweight loss. The final effect of the fight on evasion might then be to raise the marginal cost of

public funds. Policy conclusions will have to wait until the arrival of a model that considers both triangle and displacement deadweight losses, as well as of surveys that can satisfactorily overcome 
some of the challenges mentioned earlier. For the moment, we are satisfied to have pointed out a field where further research might be necessary.

\section{BIBLIOGRAPHY}

Allingham, Michael G. and Agnar Sandmo (1972). "Income Tax Evasion: A Theoretical Analysis." Journal of Public Economics, 1:323-338.

Alm, James (1985). "The welfare cost of the underground economy." Economic Inquiry, 23:24363.

Bayer, Ralph, C. (2006). "A Contest with the Taxman: the Impact of Tax Rates on Tax Evasion and Wastefully Invested Resources." European Economic Review, 50:1071-1104.

Cremer, Helmuth and Firouz Gahvari (2000). "Tax Evasion, Fiscal Competition, and Economic Integration." European Economic Review, 44:1633-1657.

Dahlberg, Matz and Anders Forslund (2005). "Direct Displacement Effects of Labour Market Programs." Scandinavian Journal of Economics, 107:475-494.

D’Elia, Enrico (2005). “Using the results of qualitative surveys in quantitative analysis.” Instituto di Studie e Analisis Economica working paper n. 56.

Harberger, Arnold C. (1964). "The Measurement of Waste." The American Economic Review, 54:58-76.

Kesselman, Jonathan R. "Policy implications of tax evasion and the underground economy." Pages 293-317 in The underground economy: global evidence of its size and impact. Edited by Owen Lippert and Michael Walker. Vancouver: The Fraser Institute, 1997.

Nardo, Michela (2003). “The Quantification of Qualitative Survey Data: A Critical Assessment." Journal of Economic Surveys 17:645-668.

Palda, Filip (1998). "Evasive Ability and the Efficiency Cost of the Underground Economy." Canadian Journal of Economics, 31:1118-1138.

-------. Tax Evasion and Firm Survival in Competitive Markets. London: Edward Elgar, 2001a.

------- (2001b), "A New Look at the Laffer Curve and the Displacement Loss from Tax Evasion", available at http://ideas.repec.org/p/wpa/wuwppe/0111006.html 
Spiro, Peter S. "Tax policy and the underground economy." Pages 179-201 in Size, Causes and Consequences of the Underground Economy. Edited by Christopher Bajada and Friedrich Schneider, Ashgate Publishing, Aldershot, England, 2005.

Tanzi, Vito. "Underground Economy and Tax Evasion in the United States: Estimates and Implication." Pages 69-92 in The Underground Economy in the United States and Abroad. Edited by Vito Tanzi. Lexington: Lexington Books, 1982.

Theil, Henri. (1952) "On the shape of economic microvariables and the Munich business test." Revue de l'Institut International de Statistique 20:105-120.

Usher, Dan (1975). "Some Questions About the Regional Development Incentives Act." Canadian Public Policy, 4:557-575.

------- (1982). "The Private Cost of Public Funds: Variations on Themes by Browning, Atkinson and Stern." Queen's Economics Department working paper \#481, Kingston, Ontario.

------- (1983). "The Benefits and Costs of Firm-Specific Investment Grants: A Study of Five Federal Programs.” Queen's University Discussion Paper 511.

- (1986). "Tax Evasion and the Marginal Cost of Public Funds." Economic Inquiry. 24:563586. 